\title{
AN EMPIRICAL ASSESSMENT ON ENVIRONMENTAL AWARENESS OF SCHOOL MANAGERS AND TEACHERS AS STAKEHOLDER OF PRIVATE SCHOOLS
}

\author{
DOI: 10.17261/Pressacademia.2017.709 \\ RJBM-V.4-ISS.3-2017(8)-p.310-325
}

\author{
Sevgi Kalkan ${ }^{1}$, Esra Demirbas ${ }^{2}$ \\ ${ }^{1}$ istanbul Yeni Yüzyıl University, 34010, Istanbul, Turkey. sevgi.kalkan@yeniyuzyil.edu.tr \\ ${ }^{2}$ istanbul Yeni Yüzyıl University, 34010, Istanbul, Turkey. esra.demirbas@yeniyuzyil.edu.tr
}

\section{To cite this document}

Kalkan, S. and E. Demirbas, (2017) An empirical assessment on environmental awareness of school managers and teachers as stakeholder of private schools, Research Journal of Business and Management (RJBM), V.4, Iss.3, p.310-325.

Permanent link to this document: http://doi.org/10.17261/Pressacademia.2017.709

Copyright: Published by Press Academia and limited licenced re-use rights only.

\begin{abstract}
Purpose- It is clear that researches on stakeholders of education contribute to responsible living in order to better understand the current situation and design sustainability. Identification of problems will contribute to the solution of problems of educational stakeholders. Education on responsible leaving is a learning process that increases student's knowledge and awareness and prepares learners to change their attitudes, then behaviors. Although there is a great deal of research on students, few empirical research attempts have been made to search environmental awareness of teachers and school managers who are most powerful stakeholders for bringing changes in education system.

Methodology- This paper will be an attempt to study an environmental awareness of teachers and school managers in private schools by their demographical qualities. In order to stimulate debates that demographical qualities influence teachers and school managers environmental awareness, a total of 418 teachers and managers were selected and an environmental awareness scale was employed to assess their knowledge, attitude and behaviors.

Findings- The results of the research show that there is significant difference between demographical qualities of school managers/teachers and their environmental awareness in terms of knowledge, attitude and behaviors.

Conclusion- Based on these researches findings, institutions should do more to promote environmental awareness programs in teacher education curricula by taking into consideration teachers and administrators demographical qualities. Instead of transmissive teaching methodologies, it is expected that institutions start to use new techniques like transformative methodologies that go beyond the teaching method to also reflect the philosophy and purpose of sustainability education
\end{abstract}

Keywords: Environmental awareness, school managers, teachers, stakeholders.

JEL Codes: 120, Q01, M10

\section{INTRODUCTION}

Education and research about environment fall within the realm of sustainable development which has been a primary purpose and overarching principle of EU and UN policies since the early 1990's. The history of environmental researches goes back to 1890 s (McCrea, 2006) and environmental education to 1920s. (Ford 1986). 'Environmental Education' (EE) refers to organized efforts to teach how natural environments function and particularly, how human beings can manage behavior and ecosystems to live sustainably. Environmental education is the teaching of individuals and communities in transitioning to a society that is knowledgeable of the environment and its associated problems, aware of the solutions to these problems and motivated to solve them. (Stapp et al. 1969). The United Nations Educational, Scientific and Cultural Organization (UNESCO) states that $\mathrm{EE}$ is vital in imparting an inherent respect for nature amongst society and in enhancing public environmental awareness.

Internationally, EE gained acknowledgement when the UN Conference on the Human Environment held in Stockholm, Sweden, in 1972, declared environmental education need be used as a instrument to address global environmental problems. In response to approval by 96 of the United Nations Conference on the Human Environment, in 1975 as a United Nations Environment Programme (UNEP) project, UNESCO/UNEP International Environmental Education Programme (IEEP) has been 
started. Its actions can be seen in following three initial stages so far (https://www.uia.org/s/or/en/1100055846 access : 09.06.2017):

i. 1975-1977 - Development of a general awareness of the necessity of environmental education : Specific activities included a series of international and regional meetings and the setting up of an international newsletter 'Connect'. Development of general awareness remains to be a principal concern.

ii. 1978-1980 - Development of concepts and methodological approaches : A series of studies and pilot projects was initiated, stressing an interdisciplinary approach. Organization of Intergovernmental Conference on Environmental Education, 1977, Tbilisi.

iii. 1981-1983 - Efforts to incorporate an environmental dimension into educational processes of UNESCO Member States. Organization of International Congress on Environmental Education and Training, 1987, Moscow (Russia), endorsing the International Strategy for Action in the Field of Environmental Education and Training for the 1990s. So far over 150 countries have been involved in IEEP events, including more than 250,000 pupils and about 12,000 teachers, from over 1,700 schools and 130 training schools and research centers. Over 60 of these countries now include environmental education throughout school curricula.

In Turkey, the precious improvements upon being constituted different foundations in order to bend the environmental problems have taken place in the recent three decades. In 1982 Turkish Constitution stipulates that every citizen has the right to live in healthy and balanced environmental standard. In 1983, the environmental law was constituted and in 1991 Ministry of Environment was founded. Due to increasing environmental problems in Turkey, environmental awareness has become a necessity. EE and researches on environment has recently become more popular in the field of education. However, despite of all these developments, researches haven't been sufficiently internalized yet. Some of these studies were undertaken with pupils, university students and graduates and prospective teachers.

This study firstly gives information about the increasing importance of education and research about environment in the world. Following the introduction, it's given the short list of recent researches in abroad and Turkey about environmental awareness. Secondly its explained the reason why teachers and school managers have been selected for this study as stakeholder of the education system, then its proposed a research model for the study. After explaining the methodology and analyzing all the findings, conclusions and recommendations have been made as the result of the research.

\section{LITERATURE REVIEW}

In Turkey in the last decades, Şama (1997) has made research called "university youth's attitudes towards environmental and environmental issues", Ayhan (1999) has examined "effecting factors on environmental awareness of students in primary school", Haktanır (2000) has worked on environmental perception of children in preschool period, Ürey(2009) has compared the environmental academic achievements and environment and human-centered attitudes of the prospective teachers . Yücel and Morgil in 1998 have found out the results on knowledge about environmental concepts and problems of secondary and higher education students (Yılmaz, Morgil, Aktuğ, Göbekli, 2002) and finally Erten (2003, 2004, 2005, 2007) has published many researches and scale studies about environmental attitudes and environmental education. In 2008, Erten has published a comparisons between German and Turkish teacher's insights to egocentric, anthropocentric and antipathetic attitudes towards environment. Baş (2011) and Bükük (2012) has completed their master thesis about "environmental consciousness levels of the teachers and school managers in secondary education public schools".

In abroad, environmental awareness is the focus of the research area for many years. For example, in 1999 Eagles, Paul and Demare (1999) made a research about factors influencing children's environmental attitudes. In Holland Kuhlemeier, Van Denberg and Lagerwejg (1999) have worked on more than 9000 students about their environmental knowledge, attitudes and behavior in Dutch secondary education, Ma and Batesone (1999) have published their study called multivariate analysis of relationship between attitudes toward science and attitudes toward the environment. The results of these students pointed out that students' gain on knowledge, attitude and behavior regarding the environment improved as a results of environmental education. The importance of $E E$ that the main actor in efforts to prevent environmental problems is to educate all the stakeholders of environmental education.

Since teachers could affect many students' knowledge, attitudes and behavior towards the environment, they are chosen as the participants for this study. The most important reason for including school managers in the study is the fact that school managers are more active in the decision making process respectively in environmental education. Istanbul is chosen for the sample which is regarded that it represents overall Turkey in many researches. Although there is a great deal of research on students, few empirical research attempts have been made to search environmental awareness of teachers and school managers who are most powerful stakeholders for bringing changes in education system. Thus, the main purpose of this study 
is to assess environmental knowledge, environmental attitude and responsible environmental behavior of managers and teachers at private schools by means of a scale which is used by Sherenk (1994) and later adapted to Turkish by Erten (2002-2003).The scale's reliability analysis was carried out according to samples and Cronbach's alpha reliability coefficients of the questionnaire were calculated as 0,678 in this study.

It is obvious that there are many factors that have been found to have influence to some extent, positive or negative on environmental awareness such as demographic factors, external factors like institutional, economic, social and cultural and internal factors such as motivation, knowledge, values, attitudes, emotion, locus of control, responsibilities and priorities. Many theoretical models have been developed so far to explain the relationships between all this factors and the environmental awareness in many studies. (Kohlberg, 1969; Kollmuss \& Agyeman, 2002; Thoresen, 2005; Dirk and Crane, 2005). Some of these models from the early 1970 s were proven to be wrong. Researches showed that in most cases, increases in knowledge did not lead to environmental behavior. (Kollmuss \& Agyeman 2002).

It is not easy task to identify only one factor alone and measure its effects on environmental awareness due to many of the variables related and interdependent to differing degrees. This could be considered as the limitation of this study. It is however following proposed model can be offered to demonstrate relations between demographical variables and environmental awareness consist of knowledge, attitude and behavior. These variables are based upon prior models (Kollmuss.\&Agyeman, 2002) in different environment researches and do not claim a comprehensive theoretical framework, instead, it suggests some further development and research. It is expected that could add to the conceptual base to develop studies for the future investigation of other stakeholders of environmental education .

Figure 1: Proposed Model of the Study

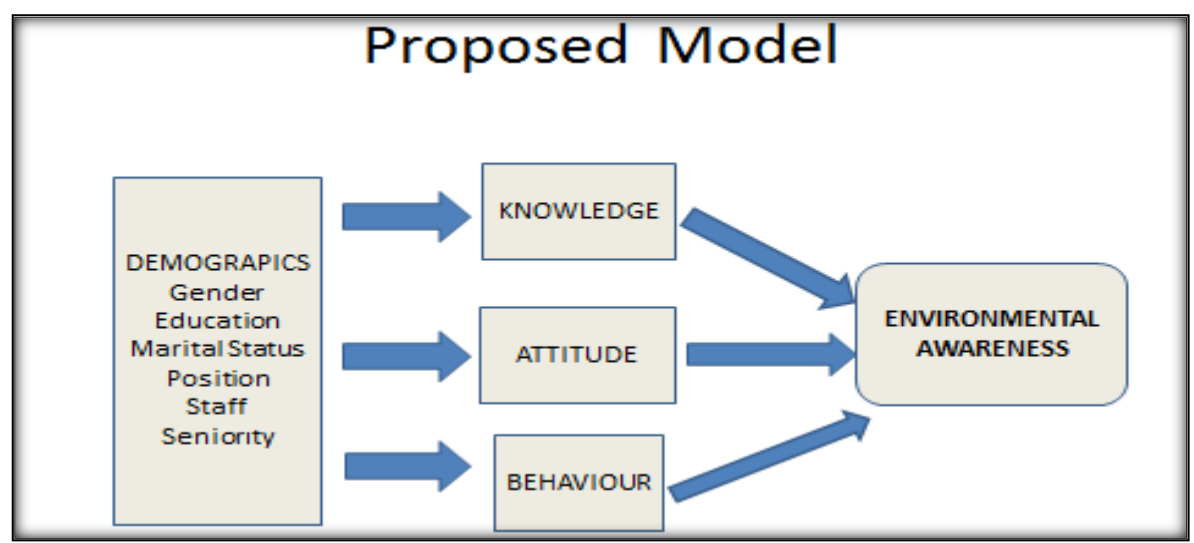

Resource : The Authors

Based on the above proposed model, the research problem and related hypothesis investigated in this study are:

What are the profiles of teachers and school managers in private schools regarding environmental awareness in terms of attitude, behavior, knowledge?

H1: There is significant difference between demographical qualities of school managers/teachers and their environmental awareness.

\section{DATA AND METHODOLOGY}

Managers and teachers working in private schools in Istanbul constitute the universe of this study. A judgmental/purposive sampling method was used to determine the sample of the research was composed with the list of Istanbul Provincial Directorate for National Education and also with the help of Private School Association. Both institutions supported the research by sending the questionnaire to directors of private schools in Istanbul to be distributed and responded.

After obtaining the necessary permits for research from the local authorities "personal information form and environmental awareness check list" developed by Erten in 2003 was applied. In this scale called environmental awareness screening list, there are 60 statements related with cognitive (knowledge), sensorial (attitude), psychomotor behavior ( behavior) towards environment. This list of scanning questions has been used in an earlier study in Germany by Sherenk in 1994 and in Turkey in two studies by Erten in 2002 and in 2003 with small changes. 
An online questionnaire is used to gather preliminary data. Each determinants of the scale has 20 items. Five points Likert as an interval scale is mainly used for the constructs of the research model. Nominal and ratio scales are also used to measure socio-demographic and economic characteristics of the sample. The propositions are from positive to negative (completely agree, agree, slightly agree, disagree, strongly disagree, with the very frequently, frequently, occasionally, very little, never). 418 informants contributed the research and 396 out of them were completely answered all questions hence five percent of the questionnaires being equal to 22 units were accepted invalid and the data analysis was realized with 396 ones. The valid response rate of the study is 94.7 per cent. The online investigation was started on February 8 th, 2017 and surveyed till April, 13 2017. The data has been analyzed with SPSS 21. program to obtain statistics.

In the first stage the data from "personal information form" which is filled by each manager and teacher in the survey, then the scores that were taken from the "list of environmental scanning" were processed. After completion of the rating process, the statistical package program SPSS for windows 21.0 was carried out to process all raw data in order to make necessary statistical analysis. Independent group t- tests were carried out in order to find out whether the environmental awareness vary significantly on gender, marital status, education level, employment positions, employment status. In case of normal distribution of categories that are more than two, one-way analysis of variance (ANOVA) was carried out in order to find out whether the responsibility levels vary significantly on the professional seniority of the sample group. In cases where meaningful difference found, complementary Scheffe tests was applied in order to find out which group is the reason of the difference.

In order to conduct factor analysis, Kaiser-Meyer-Olkin (KMO) statistic that explains how the sample presents the population and Barlett's Test of sphericity that indicates coherent relationships among sub variables to present the factor with minimum 0.05 statistical significance, are reviewed. Measures of sampling adequacy (MSA) values in the anti-image matrices and factor loading values in rotated component matrices were checked. Finally, Cronbach's Alpha statistics performed to measure reliability of items that compose a factor.

In relation to the first part of the scale, the data of frequency and percentage distribution is taken. In order to determine the attitudes of teachers and managers, arithmetic mean and standard deviation were used. To elucidate the differences between the attitudes, in binary comparisons for independent groups " $t$ " test, and in comparison of more than two groups, one-way analysis of variance variable analysis were used. Opinions on whether there is a significant difference between the $\alpha=0.05$ significance level was tested. The findings of the study are as follows ;

\section{FINDINGS AND DISCUSSIONS}

Below are tables that have compiled responses from the survey, frequency and percentage of the demographical qualities (gender, marital status, education, professional position, employment status, job seniority) of the research group, has been set. Frequency and percentage distribution of the research group is given in Table 1.

Table 1: Frequency and percentage on the basis of gender, marital status, education , professional position, employment status, job seniority

\begin{tabular}{|c|c|c|c|c|}
\hline GROUPS & Frequency & $\%$ & Valid \% & $\begin{array}{c}\text { Cumulative } \\
\%\end{array}$ \\
\hline Female & 285 & 72,0 & 72,0 & 72,0 \\
\hline Male & 111 & 28,0 & 28,0 & 1OO,O \\
\hline Single & 123 & 31,1 & 31,1 & 31,1 \\
\hline Married & 273 & 68,9 & 68,9 & 100,0 \\
\hline Graduates & 274 & 69,2 & 69,2 & 69,2 \\
\hline PostGraduates & 122 & 30,8 & 30,8 & $10 O$ \\
\hline Administrator & 52 & 13,1 & 13,1 & 13,1 \\
\hline Instructor & 344 & 86,9 & 86,9 & 100 \\
\hline Regular Staff & 262 & 66,2 & 66,2 & 66,2 \\
\hline Contractual Staff & 122 & 30,8 & 30,8 & 97,0 \\
\hline Paid Staff & 12 & 3,0 & 3,0 & 100,0 \\
\hline \multicolumn{5}{|l|}{ Seniority } \\
\hline$<=5$ years & 108 & 27,3 & 27,3 & 27,3 \\
\hline 6-10 years & 72 & 18,2 & 18,2 & 45,5 \\
\hline 11-15 years & 94 & 23,7 & 23,7 & 69,2 \\
\hline$>=16$ years & 122 & 30,8 & 30,8 & 100,0 \\
\hline TOTAL & 396 & 100,0 & 100,0 & \\
\hline
\end{tabular}


As seen in Table 1, 72 per cent of the sample group is female and 28 per cent is male. 31,1 per cent of the attendants is single and the rest $(68,9$ per cent) is married. Again table 1 presents that 69,2 per cent of the sample group has bachelor's degree and and 30,8 per cent has post graduate degree. The majority of the group(86,9 per cent) is composed by instructors (teachers). As seen in table 1, 262 attendant (66,2 per cent) are regular staff, 122 respondents (30,8 per cent) are contractual staff, and the rest 12 (3 per cent) are paid staff. 27,3 per cent of the sample has been working less than 5 years, 18,2 per cent has been working between 6-10 years and 23,7 per cent of them has been working 11-15 years and 30,8 has been working more than 16 years.

\subsection{Factor Analyses of Knowledge, Attitude and Behaviour}

Factor analysis performed in order to determine under which dimensions the respondents perceived environmental knowledge, attitude and behavior .

In order to conduct factor analysis, Kaiser-Meyer-Olkin(KMO) statistic that explains how the sample presents the population and Barlett's Test of sphericity that indicates coherent relationships among sub variables to present the factor with minimum 0.05 statistical significance, are reviewed.

As the following step, Measures of Sampling Adequacy (MSA) values of each items are checked in the anti-image matrices. Durmuş et al. (2010) recommended that "KMO evaluates integrated coherence of items for a factor whereas MSA measures individual appropriateness of each item/statement. Any item with MSA below 0.50 should be dismissed from the analysis"(p.81)

The next check point is the rotated component matrix. In this matrix, it is possible to review items with their factor loading value that means their representative skills for each factor. Meanwhile, the items are sorted based upon their representative skills under each factor. Hence, items with a factor loading beyond 0.50 are accepted as meaningful to explain this factor. Nevertheless, an item could explain more than one factor thus any item that is loaded with close values under more than one factor should be determined and loading difference less than 0.1 should not be accepted and this item should be removed from the analysis (Durmuş et al. 2010).

As a consequence of all these controls, the reliability of the scales with statistically meaningful items/statements should be examined in terms of reliability by means of Cronbach's Alpha statistic that shows the overall reliability of the items/statements within a factor. Cronbach's Alpha value beyond 0.70 means that the construct/variable is reliable. However Alpha statistics 0.60 reliability could also be accepted as a threshold for factors with a few items not less than two (Durmuş et al. 2010, p. 89).

Although the original attitude scale has twenty items in Erten(2003)'s study, the factor analysis is concluded with six items under two components that cautiousness with four items (E11, E12, E15 and E14) and concern with two items (E6 and E7). All these items have necessary correlation within themselves to explain attitude with an acceptable KMO value 0,668 and Barlett's test is 0.00 being less than 0.05 , signing appropriateness of two dimensions and their related items to conduct factor analysis. Cautiousness explains 35,20 per cent variation in an environmental attitude while concern does 32,30 per cent, in other words these two attitude factors with six items clarify 67 per cent of attitude.

There is no MSA value less than 0.5 in the anti-image matrices and there is no loading value less than 0.5 within the items of two dimensions in the rotation matrix and also there is no item has approximate loading for more than one component. The Alpha values of two extracted factors statistically explain well environmental awareness with Cronbach Alpha values of 0,728 for cautiousness and of 0,834 for concern that mean highly reliable results.

Erten(2003)'s scale measure environmental behavior with twenty items but the factor analysis of this study ended up with five items under two components. The respondents perceive environmental behavior as factors of communication (V19, V20 and $\mathrm{V} 14$ ) and consciousness (V18 and V17). All these items have necessary correlation within themselves to explain behavior with an acceptable KMO value 0,611 and Barlett's test is 0.00 being less than 0.05 , pointing out appropriateness of two dimensions and their related items to perform factor analysis. Communication explicates 36,90 per cent variation in an environmental behavior while consciousness does 32,60 per cent, in other words these two factors with five items explain 69 per cent of environmental behavior. Another variable in Erten (2003)'s scale is knowledge. This research shows that the attendants perceive knowledge within one dimension with five items, instead of twenty of the original one. These five items explain 47,34 per cent variation of the environmental knowledge with a good KMO value 0.751 and Barlett's test is 0.00 being less than 0.05 , signing appropriateness of five items to conduct factor analysis.

There is no MSA value below 0.5. Since the scale is one dimension, one component extracted hence the solution cannot be rotated. The scale is acceptably reliable with 0,678 Cronbach Alpha value.

The coming analysis of this study will continue with above five extracted factors as cautiousness, concern, communication, 
consciousness and knowledge that appeared as the environmental awareness of private school teachers and administrators.

\subsection{Means Comparison Analysis}

To clarify the changes in five factors of this study based upon the demographic variables of the respondent instructor and managers of private school; t-test is conducted to statistically compare two different groups while one-way ANOVA is applied for independent groups larger than two. Factor analyses of behavior, attitude and knowledge is given in Table $2 \mathrm{a}, 2 \mathrm{~b}$ and $2 \mathrm{c}$.

Table 2a: Factor Analyses of Knowledge

\begin{tabular}{|c|c|c|c|c|}
\hline \multicolumn{2}{|c|}{ FACTOR ANALYS IS of KNOWLEDGE } & \multirow[b]{2}{*}{$\begin{array}{r}\text { FACTOR } \\
\text { LOADING } \\
\end{array}$} & \multirow[b]{2}{*}{\begin{tabular}{|c|} 
FACTOR \\
EXPLANATION \\
$(\%)$ \\
\end{tabular}} & \multirow[b]{2}{*}{ RELIAB ILITY } \\
\hline FACTOR NAME & STATEMENT & & & \\
\hline & $\begin{array}{l}\text { W 10: Recycling paper is very } \\
\text { important for environmental } \\
\text { protection. }\end{array}$ & 0,735 & & \\
\hline & $\begin{array}{c}\text { W14: Garbages should be } \\
\text { classified and separately } \\
\text { picked up as glace, plastic, } \\
\text { paper, specific waste and } \\
\text { others. }\end{array}$ & 0,731 & & \\
\hline \multirow[t]{8}{*}{ KNOWLEDGE } & $\begin{array}{l}\text { W 12: A label should be } \\
\text { placed in a product to explain } \\
\text { whether the product is } \\
\text { environmental friendly or not. }\end{array}$ & 0,675 & 47,340 & 0,678 \\
\hline & $\begin{array}{l}\text { W11: Compost is the } \\
\text { transformation of kitchen } \\
\text { garbage into manure. }\end{array}$ & 0,654 & & \\
\hline & $\begin{array}{l}\text { W8: Recycling is a } \\
\text { transformation process of } \\
\text { garbages . }\end{array}$ & 0,641 & & \\
\hline & & TOTAL & $\mathbf{4 7 , 3 4 0}$ & \\
\hline & & $\begin{array}{l}\text { KMO } \\
\text { Kaiser- } \\
\text { Meyer } \\
\text { Olkin } \\
\end{array}$ & Scale Validity & 0,751 \\
\hline & & $\begin{array}{l}\text { Bartlett's } \\
\text { Test of } \\
\text { Sphericity }\end{array}$ & $\begin{array}{l}\text { Approx. Chi- } \\
\text { Square }\end{array}$ & 359,546 \\
\hline & & & df & 10 \\
\hline & & & significance & 0,00 \\
\hline
\end{tabular}

Table 2b. Factor Analyses of Attitude

\begin{tabular}{|c|c|c|c|c|}
\hline \multicolumn{2}{|c|}{ FACTOR ANALYSIS of ATTITUDE } & \multirow[b]{2}{*}{$\begin{array}{r}\text { FACTOR } \\
\text { LOADING } \\
\end{array}$} & \multirow[b]{2}{*}{\begin{tabular}{|c|} 
FACTOR \\
EXPLANATION \\
$(\%)$ \\
\end{tabular}} & \multirow[b]{2}{*}{ RELLABILITY } \\
\hline FACTOR NAME & STATEMENT & & & \\
\hline & $\begin{array}{l}\text { E11: I would also like to do } \\
\text { something to prevent } \\
\text { environmental pollution }\end{array}$ & 0,839 & & \\
\hline \multirow[t]{4}{*}{ CAUTIOUSNESS } & $\begin{array}{l}\text { E12: I would also like to do } \\
\text { individually something to } \\
\text { avoid air pollution. }\end{array}$ & 0,822 & 35,180 & 0,728 \\
\hline & $\begin{array}{c}\text { E15:I would like to volontarily } \\
\text { join activities to clean } \\
\text { environment }\end{array}$ & 0,614 & & \\
\hline & $\begin{array}{c}\text { E14: I spend time to interest in } \\
\text { animals and plants. }\end{array}$ & 0,563 & & \\
\hline & \begin{tabular}{|c|}
$\begin{array}{c}\text { E6: I concern not to find clean } \\
\text { water in the future }\end{array}$ \\
\end{tabular} & 0,872 & 32,268 & \\
\hline \multirow[t]{6}{*}{ CONCERN } & $\begin{array}{l}\text { E7: People could have } \\
\text { diseases, even die due to air } \\
\text { pollution, in the future. }\end{array}$ & 0,845 & & 0,834 \\
\hline & & TOTAL & 67,448 & \\
\hline & & $\begin{array}{l}\text { KMO } \\
\text { Kaiser- } \\
\text { Meyer } \\
\text { Olkin } \\
\end{array}$ & Scale Validity & 0,668 \\
\hline & & $\begin{array}{l}\text { Bartlett's } \\
\text { Test of } \\
\text { Sphericity } \\
\end{array}$ & $\begin{array}{l}\text { Approx. Chi- } \\
\text { Square }\end{array}$ & 870,628 \\
\hline & & & df & 15 \\
\hline & & & significance & 0,00 \\
\hline
\end{tabular}


Table 2c: Factor Analyses of Behavior

\begin{tabular}{|c|c|c|c|c|}
\hline \multicolumn{5}{|c|}{ FACTOR ANALYSIS of BEHAVIOUR } \\
\hline \multirow[t]{2}{*}{ FACTOR NAME } & STATEMENT & $\begin{array}{c}\text { FACTOR } \\
\text { LOADING }\end{array}$ & $\begin{array}{c}\text { FACTOR } \\
\text { EXPLANATION } \\
(\%) \\
\end{array}$ & RELIABILITY \\
\hline & $\begin{array}{c}\text { V19: I frequently attend } \\
\text { events about environmental } \\
\text { protection }\end{array}$ & 0,843 & & \\
\hline \multirow[t]{3}{*}{ COMMUNICATION } & $\begin{array}{l}\text { V20: I informed responsible } \\
\text { people in order to prevent } \\
\text { environmental pollution }\end{array}$ & 0,790 & 36,897 & 0,685 \\
\hline & $\begin{array}{l}\text { V14: I talk with my friends on } \\
\text { environmental pollution }\end{array}$ & 0,707 & & \\
\hline & $\begin{array}{l}\text { V18: I am keen on put off } \\
\text { electricity and electronic } \\
\text { divices when I do not use } \\
\text { them. }\end{array}$ & 0,872 & & \\
\hline \multirow[t]{6}{*}{ CONSCIOUSNESS } & V17: I carefully turn off tap. & 0,845 & 32,258 & 0,691 \\
\hline & & TOTAL & 69,155 & \\
\hline & & $\begin{array}{l}\text { KMO } \\
\text { Kaiser- } \\
\text { Meyer } \\
\text { Olkin }\end{array}$ & Scale Validity & 0,611 \\
\hline & & $\begin{array}{l}\text { Bartlett's } \\
\text { Test of } \\
\text { Sphericity }\end{array}$ & $\begin{array}{l}\text { Approx. Chi- } \\
\text { Square }\end{array}$ & 386,385 \\
\hline & & & df & 10 \\
\hline & & & significance & 0,00 \\
\hline
\end{tabular}

\subsubsection{T Tests}

Since gender, marital status, education and position variables are measured with two groups nominal scales and concern, cautiousness, communication, consciousness and knowledge are measured with a five point likert scale, $t$-test are conducted to determine difference between the means of two groups as seen the below tables 3 . Equality of variance affects the result of t-test. Therefore, an homogeneity test-"Levene's test " is applied first to clarify the equality of variances of two groups. Following hypothesis are questioned at the beginning of each t-test.

Ho_v: The variances of two groups are the same.

HI_v: The variances of two groups are different.

To test the above start-up hypothesis, $F$ values are observed. If significance value of $F$ is greater than 0,05 , Ho should be accepted otherwise should be rejected (Durmuş 2010, p.118). In case of the acceptance Hov, first row significance is considered in t-test table otherwise in case of Hov rejection, the second row is.

Following the variance equality, independent group t-test hypothesis below are questioned.

$H_{O_{-}}$: Means of two groups are equal (the same)

$H_{I_{-}}$: Means of two groups are not equal (are different)

If significance is greater than $0.05, \mathrm{HO}$ is accepted, meaning that there is no difference between the means of two groups. If significance is less than 0.05 , the difference between means are arise to be confirmed in the t-test tables.

\subsubsection{Gender}

An independent group t- test was carried out in order to find out whether the environmental concern, environmental 
cautiousness, communication on environment, consciousness in environment and environmental knowledge, vary significantly on the basis of gender; and it was seen that there are significant differences between female and male teachers and administrators in terms of environmental concern and knowledge. Both knowledge and concern about environment of Females private school teachers' environmental knowledge $(4,54)$ and concern $(4,75)$ are higher than males' averages $(4,33$ and $4,50)$. There is no difference between female and male groups in terms of environmental cautiousness, consciousness and communication.

Women who have more knowledge on environment, could understand and imagine the dangerous results of unprotected environment, accordingly could have more environmental concern.

Table 3.a: Environmental Concern, Cautiousness, Communication, Consciousness and Knowledge on the Basis of Gender

\begin{tabular}{|c|c|c|c|c|c|c|c|c|c|c|c|c|c|c|}
\hline \multirow[b]{3}{*}{ Point } & \multirow[b]{3}{*}{ Sex } & \multirow[b]{3}{*}{$\mathrm{n}$} & \multirow[b]{3}{*}{ Mean } & \multirow[b]{3}{*}{$\begin{array}{c}\text { Std. } \\
\text { Deviation }\end{array}$} & \multirow[b]{3}{*}{\begin{tabular}{|c|}
$\begin{array}{c}\text { Std. Error } \\
\text { Mean }\end{array}$ \\
\end{tabular}} & \multicolumn{2}{|c|}{$\begin{array}{l}\text { Levene's Test } \\
\text { for Equality } \\
\text { of Variances }\end{array}$} & \multicolumn{7}{|c|}{ t-test for Equality of Means } \\
\hline & & & & & & \multirow[b]{2}{*}{$\mathbf{F}$} & \multirow[b]{2}{*}{ Sig. } & \multirow[b]{2}{*}{$t$} & \multirow[b]{2}{*}{$\mathrm{df}$} & \multirow[b]{2}{*}{$\begin{array}{l}\text { Sig. (2- } \\
\text { tailed) }\end{array}$} & \multirow[b]{2}{*}{$\begin{array}{c}\text { Mean } \\
\text { Difference }\end{array}$} & \multirow[b]{2}{*}{$\begin{array}{l}\text { Std. Error } \\
\text { Differeace }\end{array}$} & \multicolumn{2}{|c|}{$\begin{array}{l}\text { Confidence } \\
\text { Interval of the }\end{array}$} \\
\hline & & & & & & & & & & & & & Lower & Upper \\
\hline \multirow[t]{2}{*}{ Concern } & Female & 285 & 4,751 & 0,546 & 0,032 & 2,641 & 0,105 & 1,483 & 394 & 0,139 & 0,108 & 0,073 & $-0,035$ & 0,251 \\
\hline & Male & 111 & 4,500 & 0,710 & 0,067 & & & 1,427 & 185,903 & 0,155 & 0,108 & 0,076 & $-0,041$ & 0,257 \\
\hline \multirow{2}{*}{ Cautiousness } & Female & 285 & 4,3623 & 0,633 & 0,037 & 2,641 & 0,105 & 1,483 & 394 & 0,139 & 0,108 & 0,073 & $-0,035$ & 0,251 \\
\hline & Male & 111 & 4,2545 & 0,691 & 0,066 & & & 1,427 & 185,903 & 0,155 & 0,108 & 0,076 & $.0,041$ & 0,257 \\
\hline \multirow[t]{2}{*}{ Communication } & Female & 285 & 2,793 & 0,805 & 0,048 & 0,133 & 0,715 & $\cdot 2,945$ & 394 &, 003 & $=, 27008$ &, 09170 &,- 45037 &,- 08980 \\
\hline & Male & 111 & 3,063 & 0,856 & 0,081 & & & $\cdot 2,867$ & 190,171 &, 005 & $\cdot, 27008$ & ,09419 &,- 45588 &,- 08428 \\
\hline \multirow[t]{2}{*}{ Concioussness } & Female & 285 & 4,761 & 0,496 & 0,029 & 4,520 & 0,034 & 1,558 & 394 & 0,120 & 0,095 & 0,061 & $=0,025$ & 0,214 \\
\hline & Male & 111 & 4,667 & 0,651 & 0,062 & & & 1,384 & 162,025 & 0,168 & 0,095 & 0,068 & $-0,040$ & 0,230 \\
\hline \multirow[t]{2}{*}{ Knowledge } & Female & 285 & 4,5354 & 0,459 & 0,027 & 20,640 & 0,000 & 3,476 & 394 & 0,001 & 0,206 & 0,059 & 0,089 & 0,322 \\
\hline & Male & 111 & 4,3297 & 0,677 & 0,064 & & & 2,948 & 150,964 & 0,004 & 0,206 & 0,070 & 0,068 & 0,344 \\
\hline
\end{tabular}

\subsubsection{Education}

Managers' and instructors' environmental concern, environmental cautiousness, communication on environment, consciousness in environment and environmental knowledge have been questioned on the basis of education as it is presented in table 3.b. Any difference is not seen between graduate and post-graduate teachers in terms of environmental concern, cautiousness, communication, consciousness and knowledge. 
Table 3.b: Environmental Concern, Cautiousness, Communication, Consciousness and Knowledge on the Basis of Education

\begin{tabular}{|c|c|c|c|c|c|c|c|c|c|c|c|c|c|c|}
\hline \multirow[b]{3}{*}{ Point } & \multirow[b]{3}{*}{$\begin{array}{c}\text { Marital } \\
\text { Status } \\
\end{array}$} & \multirow[b]{3}{*}{$\mathbf{n}$} & \multirow[b]{3}{*}{ Mean } & \multirow[b]{3}{*}{$\begin{array}{c}\text { Std. } \\
\text { Deviation }\end{array}$} & \multirow[b]{3}{*}{$\begin{array}{c}\text { Std. Error } \\
\text { Mean }\end{array}$} & \multicolumn{2}{|c|}{$\begin{array}{l}\text { Levene's Test } \\
\text { for Equality } \\
\text { of Variances }\end{array}$} & \multicolumn{7}{|c|}{ t-test for Equality of Means } \\
\hline & & & & & & \multirow[b]{2}{*}{$\mathbf{F}$} & \multirow[b]{2}{*}{ Sig. } & \multirow[b]{2}{*}{$\mathbf{t}$} & \multirow[b]{2}{*}{ df } & \multirow[b]{2}{*}{$\begin{array}{l}\text { Sig. (2- } \\
\text { tailed) }\end{array}$} & \multirow[b]{2}{*}{$\begin{array}{c}\text { Mean } \\
\text { Difference }\end{array}$} & \multirow[b]{2}{*}{\begin{tabular}{|c} 
Std. Error \\
Difference
\end{tabular}} & \multicolumn{2}{|c|}{$\begin{array}{c}\text { Confidence } \\
\text { Interval of the }\end{array}$} \\
\hline & & & & & & & & & & & & & Lower & Upper \\
\hline \multirow[t]{2}{*}{ Concern } & Graduate & 274 & 4,666 & 0,637 & 0,038 & 2,289 & 0,131 & $-0,712$ & 394 & 0,477 & $-0,047$ & 0,066 & $-0,177$ & 0,083 \\
\hline & Post-Graduate & 122 & 4,713 & 0,534 & 0,048 & & & $-0,762$ & 274,202 & 0,447 & $-0,047$ & 0,062 & $-0,169$ & 0,075 \\
\hline \multirow[t]{2}{*}{ Cautiousness } & Graduate & 274 & 4,343 & 0,635 & 0,038 & 1,786 & 0,182 & 0,504 & 394 & 0,615 & 0,036 & 0,071 & $-0,104$ & 0,175 \\
\hline & Post-Graduate & 122 & 4,307 & 0,685 & 0,062 & & & 0,489 & 217,449 & 0,625 & 0,036 & 0,073 & $-0,108$ & 0,179 \\
\hline \multirow[t]{2}{*}{ Communication } & Graduate & 274 & 2,883 & 0,815 & 0,049 & 0,229 & 0,632 & 0,523 & 394 & 0,601 & 0,047 & 0,090 & $-0,130$ & 0,224 \\
\hline & Post-Graduate & 122 & 2,836 & 0,857 & 0,078 & & & 0,513 & 222,046 & 0,609 & 0,047 & 0,092 & $-0,134$ & 0,228 \\
\hline \multirow[t]{2}{*}{ Concioussness } & Graduate & 274 & 4,754 & 0,500 & 0,030 & 3,772 & 0,053 & 1,030 & 394 & 0,304 & 0,061 & 0,059 & $-0,056$ & 0,178 \\
\hline & Post-Graduate & 122 & 4,693 & 0,635 & 0,057 & & & 0,940 & 190,554 & 0,348 & 0,061 & 0,065 & $-0,067$ & 0,189 \\
\hline \multirow[t]{2}{*}{ Knowledge } & Graduate & 274 & 4,474 & 0,507 & 0,031 & 0,719 & 0,397 & $-0,185$ & 394 & 0,854 & $-0,011$ & 0,058 & $-0,126$ & 0,104 \\
\hline & Post-Graduate & 122 & 4,485 & 0,599 & 0,054 & & & $-0,173$ & 201,612 & 0,863 & $-0,011$ & 0,062 & $-0,134$ & 0,112 \\
\hline
\end{tabular}

\subsubsection{Position}

Teachers' environmental awareness has been investigated according to their position. Both administrators and instructors have the same levels of concern, cautiousness, consciousness and knowledge about environmental issues whereas communication on environment differs between these two groups. Managers (with a mean of 3,2051) communicate more on environmental issues than instructors (with a mean of 2,8178).

Table 3.c: Environmental Concern, Cautiousness, Communication, Consciousness and Knowledge on the basis of Position

\begin{tabular}{|c|c|c|c|c|c|c|c|c|c|c|c|c|c|c|}
\hline \multirow[b]{3}{*}{ Point } & \multirow[b]{3}{*}{$\begin{array}{c}\text { Marital } \\
\text { Status }\end{array}$} & \multirow[b]{3}{*}{$\mathbf{n}$} & \multirow[b]{3}{*}{ Mean } & \multirow[b]{3}{*}{\begin{tabular}{|c|} 
Std. \\
Deviation
\end{tabular}} & \multirow[b]{3}{*}{$\begin{array}{c}\begin{array}{c}\text { Std. Error } \\
\text { Mean }\end{array} \\
\end{array}$} & \multicolumn{2}{|c|}{$\begin{array}{l}\text { Levene's Test } \\
\text { for Equality } \\
\text { of Variances }\end{array}$} & \multicolumn{7}{|c|}{ t-test for Equality of Means } \\
\hline & & & & & & \multirow[b]{2}{*}{$\mathbf{F}$} & \multirow[b]{2}{*}{ Sig. } & \multirow[b]{2}{*}{$t$} & \multirow[b]{2}{*}{ df } & \multirow[b]{2}{*}{$\begin{array}{l}\text { Sig. (2- } \\
\text { tailed) }\end{array}$} & \multirow[b]{2}{*}{$\begin{array}{c}\text { Mean } \\
\text { Difference }\end{array}$} & \multirow[b]{2}{*}{\begin{tabular}{|} 
Std. Error \\
Difference
\end{tabular}} & \multicolumn{2}{|c|}{$\begin{array}{c}\text { Confidence } \\
\text { Interval of the }\end{array}$} \\
\hline & & & & & & & & & & & & & Lower & Upper \\
\hline \multirow[t]{2}{*}{ Concern } & Administrator & 52 & 4,692 & 0,487 & 0,067 & 0,932 & 0,335 & 0,150 & 394 & 0,881 & 0,014 & 0,090 & $-0,164$ & 0,191 \\
\hline & Instructor & 344 & 4,679 & 0,623 & 0,034 & & & 0,179 & 78,713 & 0,858 & 0,014 & 0,075 & $-0,137$ & 0,164 \\
\hline \multirow[t]{2}{*}{ Cautiousness } & Administrator & 52 & 4,308 & 0,602 & 0,083 & 0,083 & 0,773 & $-0,290$ & 394 & 0,772 & $-0,028$ & 0,097 & $-0,219$ & 0,162 \\
\hline & Instructor & 344 & 4,336 & 0,658 & 0,035 & & & $-0,310$ & 70,788 & 0,758 & $-0,028$ & 0,091 & $-0,209$ & 0,153 \\
\hline \multirow[t]{2}{*}{ Communication } & Administrator & 52 & 3,205 & 0,557 & 0,077 & 9,471 & 0,002 & 3,182 & 394 & 0,002 & 0,387 & 0,122 & 0,148 & 0,627 \\
\hline & Instructor & 344 & 2,818 & 0,850 & 0,046 & & & 4,313 & 91,588 & 0,000 & 0,387 & 0,090 & 0,209 & 0,566 \\
\hline \multirow[t]{2}{*}{ Concioussness } & Administrator & 52 & 4,808 & 0,385 & 0,053 & 4,122 & 0,043 & 1,035 & 394 & 0,301 & 0,084 & 0,081 & $-0,075$ & 0,243 \\
\hline & Instructor & 344 & 4,724 & 0,564 & 0,030 & & & 1,363 & 88,043 & 0,176 & 0,084 & 0,062 & $-0,038$ & 0,206 \\
\hline \multirow[t]{2}{*}{ Knowledge } & Administrator & 52 & 4,442 & 0,548 & 0,076 & 0,060 & 0,807 & $-0,511$ & 394 & 0,609 & $-0,041$ & 0,080 & $-0,198$ & 0,116 \\
\hline & Instructor & 344 & 4,483 & 0,535 & 0,029 & & & $-0,502$ & 66,566 & 0,617 & $-0,041$ & 0,081 & $-0,203$ & 0,121 \\
\hline
\end{tabular}

\subsubsection{Marital Status}

Teachers' and administrators' levels of environmental concern, environmental cautiousness, communication on environment, consciousness in environment and environmental knowledge, based upon marital status have been presented in table 3.d. No difference between married and single teachers appears in terms of environmental concern, cautiousness, communication, consciousness and knowledge. 
Table 3.d: Environmental Concern, Cautiousness, Communication, Consciousness and Knowledge on the basis of Marital Status

\begin{tabular}{|c|c|c|c|c|c|c|c|c|c|c|c|c|c|c|}
\hline \multirow[b]{3}{*}{ Point } & \multirow[b]{3}{*}{$\begin{array}{c}\text { Marital } \\
\text { Status }\end{array}$} & \multirow[b]{3}{*}{$\mathbf{n}$} & \multirow[b]{3}{*}{ Mean } & \multirow[b]{3}{*}{$\begin{array}{c}\text { Std. } \\
\text { Deviation }\end{array}$} & \multirow[b]{3}{*}{$\begin{array}{c}\begin{array}{c}\text { Std. Frror } \\
\text { Mean }\end{array} \\
\end{array}$} & \multicolumn{2}{|c|}{\begin{tabular}{|} 
Levene's Test \\
for Equality \\
of Variances
\end{tabular}} & \multicolumn{7}{|c|}{ t-test for Equality of Means } \\
\hline & & & & & & \multirow[b]{2}{*}{$\mathbf{F}$} & \multirow[b]{2}{*}{ Sig. } & \multirow[b]{2}{*}{$\mathbf{t}$} & \multirow[b]{2}{*}{ df } & \multirow[b]{2}{*}{$\begin{array}{l}\text { Sig. (2- } \\
\text { tailed) }\end{array}$} & \multirow[b]{2}{*}{$\begin{array}{c}\text { Mean } \\
\text { Difference }\end{array}$} & \multirow[b]{2}{*}{$\begin{array}{c}\text { Std. Error } \\
\text { Difference }\end{array}$} & \multicolumn{2}{|c|}{$\begin{array}{l}\text { Confidence } \\
\text { Interval of the }\end{array}$} \\
\hline & & & & & & & & & & & & & Lower & Upper \\
\hline \multirow[t]{2}{*}{ Concern } & Single & 123 & 4,7114 & 0,587 & 0,053 & 1,154 & 0,283 & 0,678 & 394 & 0,498 & 0,045 & 0,066 & $-0,085$ & 0,174 \\
\hline & Married & 273 & 4,6667 & 0,616 & 0,037 & & & 0,691 & 245,982 & 0,490 & 0,045 & 0,065 & $-0,083$ & 0,172 \\
\hline \multirow[t]{2}{*}{ Cautiousness } & Single & 123 & 4,327 & 0,659 & 0,059 & 0,046 & 0,831 & $\mid-0,099$ & 394 & 0,921 & $-0,007$ & 0,071 & $-0,146$ & 0,132 \\
\hline & Married & 273 & 4,334 & 0,648 & 0,039 & & & $-0,099$ & 231,518 & 0,922 & $-0,007$ & 0,071 & $-0,147$ & 0,133 \\
\hline \multirow[t]{2}{*}{ Communication } & Single & 123 & 2,856 & 0,858 & 0,077 & 0,291 & 0,590 & $-0,199$ & 394 & 0,843 & $-0,018$ & 0,090 & $-0,195$ & 0,159 \\
\hline & Married & 273 & 2,874 & 0,815 & 0,049 & & & $-0,195$ & 225 & 0,846 & $-0,018$ & 0,092 & $-0,199$ & 0,163 \\
\hline \multirow[t]{2}{*}{ Concioussness } & Single & 123 & 4,683 & 0,581 & 0,052 & 3,306 & 0,070 & $-1,274$ & 394 & 0,203 & $-0,075$ & 0,059 & $-0,191$ & 0,041 \\
\hline & Married & 273 & 4,758 & 0,527 & 0,032 & & & $-1,228$ & 216,015 & 0,221 & $-0,075$ & 0,061 & $-0,196$ & 0,046 \\
\hline \multirow[t]{2}{*}{ Knowledge } & Single & 123 & 4,504 & 0,499 & 0,045 & 1,491 & 0,223 & 0,654 & 394 & 0,513 & 0,038 & 0,058 & $-0,076$ & 0,153 \\
\hline & Married & 273 & 4,466 & 0,553 & 0,033 & & & 0,680 & 258,439 & 0,497 & 0,038 & 0,056 & $-0,072$ & 0,149 \\
\hline
\end{tabular}

\subsubsection{Seniority}

Since teachers' seniority is measured with four groups one-way ANOVA test conducted to determine difference between the means of four groups as seen the below Table 4.a. No difference appeared among groups in terms of environmental concern, environmental cautiousness and environmental knowledge. The means of these groups are approximate for these factors.

Nevertheless, environmental communication and environmental consciousness vary according to the years of seniority. As it is seen in table 4.a Teachers who have been working more than sixteen years, communicate more on environmental issues in the society. 
Table 4.a: Environmental Concern, Cautiousness, Communication, Consciousness and Knowledge on the basis of Seniority

\begin{tabular}{|c|c|c|c|c|c|c|c|c|c|c|}
\hline points & Seniority & $\mathbf{N}$ & $\mathbf{x}$ & Sd & Var.K. & $\begin{array}{c}\text { Sum of } \\
\text { Squares }\end{array}$ & df & $\begin{array}{c}\text { Mean } \\
\text { Square }\end{array}$ & $\mathbf{F}$ & Significance \\
\hline \multirow[t]{7}{*}{ Concern } & $<=5$ years & 108 & 4,6389 & 0,659 & $\begin{array}{c}\text { Between } \\
\text { Groups }\end{array}$ & 0,545 & 3 & 0,182 & 0,491 & $\begin{array}{l}0,688 \\
>0,05\end{array}$ \\
\hline & $6-10$ years & 72 & 4,6458 & 0,613 & $\begin{array}{l}\text { Within } \\
\text { Groups }\end{array}$ & 144,796 & 392 & 0,369 & & \\
\hline & $11-15$ years & 94 & 4,6968 & 0,610 & Total & 145,340 & 395 & & & \\
\hline & $>=16$ years & 122 & 4,7254 & 0,553 & $\begin{array}{l}\text { Levene } \\
\text { Statistic }\end{array}$ & 1,294 & & & & \\
\hline & Tota1 & 396 & 4,6806 & 0,607 & df1 & 3 & & & & \\
\hline & & & & & df2 & 392 & & & & \\
\hline & & & & & Sig. & 0,276 & & & & \\
\hline \multirow[t]{7}{*}{ Cautiousness } & $<=5$ years & 108 & 4,2407 & 0,723 & $\begin{array}{c}\text { Between } \\
\text { Groups }\end{array}$ & 1,524 & 3 & 0,508 & 1,203 & $\begin{array}{l}0,308 \\
>0,05\end{array}$ \\
\hline & $6-10$ years & 72 & 4,3125 & 0,670 & $\begin{array}{l}\text { Within } \\
\text { Groups }\end{array}$ & 165,559 & 392 & 0,422 & & \\
\hline & $11-15$ years & 94 & 4,3777 & 0,620 & Total & 167,083 & 395 & & & \\
\hline & $>=16$ years & 122 & 4,3893 & 0,589 & $\begin{array}{l}\text { Levene } \\
\text { Statistic }\end{array}$ & 1,002 & & & & \\
\hline & Tota1 & 396 & 4,3321 & 0,650 & df1 & 3 & & & & \\
\hline & & & & & df2 & 392 & & & & \\
\hline & & & & & Sig. & 0,392 & & & & \\
\hline \multirow[t]{7}{*}{ Communication } & $z=5$ years & 108 & 2,750 & 0,862 & $\begin{array}{c}\text { Between } \\
\text { Groups }\end{array}$ & 14,268 & 3 & 4,756 & 7,276 & $\begin{array}{c}0 * \\
<0,05\end{array}$ \\
\hline & $6-10$ years & 72 & 2,731 & 0,720 & $\begin{array}{l}\text { Within } \\
\text { Groups }\end{array}$ & 256,237 & 392 & 0,654 & & \\
\hline & $11-15$ years & 94 & 2,741 & 0,875 & Total & 270,505 & 395 & & & \\
\hline & $>=16$ years & 122 & 3,153 & 0,754 & $\begin{array}{l}\text { Levene } \\
\text { Statistic }\end{array}$ & 2,153 & & & & \\
\hline & Tota1 & 396 & 2,869 & 0,828 & df1 & 3 & & & & \\
\hline & & & & & df2 & 392 & & & & \\
\hline & & & & & Sig. & 0,093 & & & & \\
\hline \multirow[t]{7}{*}{ Conciousness } & $<=5$ years & 108 & 4,6667 & 0,649 & $\begin{array}{c}\text { Between } \\
\text { Groups }\end{array}$ & 3,156 & 3 & 1,052 & 3,617 & $0,013 * *$ \\
\hline & $6-10$ years & 72 & 4,6111 & 0,640 & $\begin{array}{l}\text { Within } \\
\text { Groups }\end{array}$ & 114,003 & 392 & 0,291 & & \\
\hline & $11-15$ years & 94 & 4,7660 & 0,496 & Total & 117,159 & 395 & & & \\
\hline & $>=16$ years & 122 & 4,8443 & 0,375 & $\begin{array}{l}\text { Levene } \\
\text { Statistic }\end{array}$ & 10,819 & & & & \\
\hline & Tota1 & 396 & 4,7348 & 0,545 & df1 & 3 & & & & \\
\hline & & & & & df2 & 392 & & & & \\
\hline & & & & & Sig. & 0,000 & & & & \\
\hline \multirow[t]{7}{*}{ Knowledge } & $z=5$ yrears & 108 & 4,370 & 0,635 & $\begin{array}{c}\text { Between } \\
\text { Groups }\end{array}$ & 1,920 & 3 & 0,640 & 2,247 & 0,082 \\
\hline & $6-10$ years & 72 & 4,475 & 0,523 & $\begin{array}{l}\text { Within } \\
\text { Groups }\end{array}$ & 111,684 & 392 & 0,285 & & \\
\hline & $11-15$ years & 94 & 4,519 & 0,473 & Total & 113,604 & 395 & & & \\
\hline & $>=16$ years & 122 & 4,543 & 0,483 & $\begin{array}{c}\text { Levene } \\
\text { Statistic }\end{array}$ & 2,100 & & & & \\
\hline & Tota1 & 396 & 4,478 & 0,536 & df1 & 3 & & & & \\
\hline & & & & & df2 & 392 & & & & \\
\hline & & & & & Sig. & 0,100 & & & & \\
\hline
\end{tabular}

\subsubsection{Sheffe Test}

To make the post-hoc analysis, Scheffe test is chosen due to different respondents volume of four seniority groups. Scheffe test confirms the variation within groups and it is seen that the mean $(3,1530)$ of the group equal and longer than sixteen years, is higher than other three groups $(2,75 ; 2,7315$ and 2,7411$)$. 
Table 4b: Seniority Groups

\begin{tabular}{|c|c|c|c|c|c|c|c|}
\hline \multicolumn{8}{|c|}{ Multiple Comparisons } \\
\hline $\begin{array}{l}\text { Dependent } \\
\text { Variable: }\end{array}$ & \multicolumn{2}{|c|}{ COMMUNICATION } & & & & & \\
\hline & & & \multirow{2}{*}{$\begin{array}{c}\text { Mean } \\
\text { Difference } \\
(\mathrm{I}-\mathrm{J})\end{array}$} & \multirow[b]{2}{*}{ Std. Error } & \multirow[b]{2}{*}{ Sig. } & \multicolumn{2}{|c|}{$95 \%$ Confidence Interval } \\
\hline & & & & & & $\begin{array}{l}\text { Lower } \\
\text { Bound }\end{array}$ & $\begin{array}{l}\text { Upper } \\
\text { Bound }\end{array}$ \\
\hline & (I)Seniority & $(\mathrm{J})$ Seniority & & & & & \\
\hline \multirow[t]{12}{*}{ Scheffe } & \multirow{3}{*}{$\begin{array}{l}5 \text { YIL ve } \\
\text { ALTI }\end{array}$} & 6-10 YIL & 0,019 & 0,123 & 0,999 & $-0,327$ & 0,364 \\
\hline & & $11-15$ YIL & 0,009 & 0,114 & 1,000 & $-0,311$ & 0,329 \\
\hline & & $\begin{array}{l}16 \text { YIL ve } \\
\text { UST U }\end{array}$ &,$- 40301^{*}$ & 0,107 & 0,003 & $-0,703$ & $-0,103$ \\
\hline & \multirow[t]{3}{*}{ 6-10 YIL } & $\begin{array}{l}5 \text { YIL ve } \\
\text { ALT I }\end{array}$ & $-0,019$ & 0,123 & 0,999 & $-0,364$ & 0,327 \\
\hline & & $11-15$ YIL & $-0,010$ & 0,127 & 1,000 & $-0,365$ & 0,346 \\
\hline & & $\begin{array}{l}16 \text { YIL ve } \\
\text { USTU }\end{array}$ &,$- 42152^{*}$ & 0,120 & 0,007 & $-0,759$ & $-0,084$ \\
\hline & \multirow[t]{3}{*}{$11-15$ YIL } & $\begin{array}{l}5 \text { YIL ve } \\
\text { ALTI }\end{array}$ & $-0,009$ & 0,114 & 1,000 & $-0,329$ & 0,311 \\
\hline & & 6-10 YIL & 0,010 & 0,127 & 1,000 & $-0,346$ & 0,365 \\
\hline & & $\begin{array}{l}16 \text { YIL ve } \\
\text { USTU }\end{array}$ &,$- 41187^{*}$ & 0,111 & 0,004 & $-0,723$ & $-0,100$ \\
\hline & \multirow[t]{3}{*}{$\begin{array}{l}16 \text { YIL ve } \\
\text { UST U }\end{array}$} & $\begin{array}{l}5 \text { YIL ve } \\
\text { ALTI }\end{array}$ & $0,40301 *$ & 0,107 & 0,003 & 0,103 & 0,703 \\
\hline & & 6-10 YIL & $0,41152 *$ & 0,120 & 0,007 & 0,084 & 0,759 \\
\hline & & $11-15$ YIL & $0,41187 *$ & 0,111 & 0,004 & 0,100 & 0,723 \\
\hline
\end{tabular}

*. The mean difference is significant at the 0.05 level.

As it is seen in table 4.a, the variances of seniority groups are not equal hence the start-up condition of one-way ANOVA could not be obtained. As an alternative way, Welch and Brown-Forsythe tests was conducted to precise the differentiation. Finally, both significance value of Welch $(0,009)$ and Brown-Forsythe $(0,018)$ are less than 0,05 , difference within seniority groups in consciousness could be stated.

\subsubsection{Welch}

In an analysis of variance, it may happen that the variances cannot be assumed to be equal. In this case, the $F$ test of the ANOVA is not robust enough to be used. That's why Welch test is chosen due to Welch and Brown-Forsythe ANOVA are more reliable than the classic $\mathrm{F}$ when variances are unequal. 
Table 4c: Seniority Groups

\begin{tabular}{|l|r|r|c|c|}
\hline \multicolumn{5}{|c|}{ Robust Tests of Equality of Means } \\
CONCIOUSNESS \\
\hline & Statistic $^{\text {a }}$ & df1 & df2 & Sig. \\
\hline $\begin{array}{l}\text { Welch } \\
\text { Brown- } \\
\text { Forsythe }\end{array}$ & 3,945 & 3 & 189,663 & 0,009 \\
\cline { 2 - 5 } & 3,408 & 3 & 294,222 & 0,018 \\
\hline \multicolumn{4}{|l|}{ a. Asymptotically F distributed. } \\
\hline
\end{tabular}

Below Scheffe test shows that the consciousness of seniorities of between 6-10 years and of equal and higher than 16 years differ.

Table 4d: Consciousness of Seniority Groups

\begin{tabular}{|c|c|c|c|c|c|c|c|}
\hline \multicolumn{8}{|c|}{ Multiple Comparisons } \\
\hline \multirow[t]{3}{*}{ Variable: } & \multicolumn{2}{|c|}{ CONCIOUSNESS } & & & \multirow[b]{3}{*}{ Sig. } & & \\
\hline & & & \multirow{2}{*}{$\begin{array}{c}\text { Mean } \\
\text { Difference } \\
(\mathbf{I}-\mathbf{J})\end{array}$} & \multirow[b]{2}{*}{ Std. Error } & & \multicolumn{2}{|c|}{ 95\% Confidence Interval } \\
\hline & & & & & & $\begin{array}{l}\text { Lower } \\
\text { Bound }\end{array}$ & $\begin{array}{l}\text { Upper } \\
\text { Bound }\end{array}$ \\
\hline & (I)Seniority & (J)Seniority & & & & & \\
\hline \multirow[t]{12}{*}{ Scheffe } & \multirow{3}{*}{$\begin{array}{l}5 \text { YIL ve } \\
\text { ALTI }\end{array}$} & 6-10 YIL & 0,056 & 0,082 & 0,928 & $-0,175$ & 0,286 \\
\hline & & $11-15$ YIL & $-0,099$ & 0,076 & 0,636 & $-0,313$ & 0,114 \\
\hline & & $\begin{array}{l}16 \text { YIL ve } \\
\text { USTU }\end{array}$ & $-0,178$ & 0,071 & 0,104 & $-0,378$ & 0,022 \\
\hline & \multirow[t]{3}{*}{ 6-10 YIL } & $\begin{array}{l}5 \text { YIL ve } \\
\text { ALTI }\end{array}$ & $-0,056$ & 0,082 & 0,928 & $-0,286$ & 0,175 \\
\hline & & $11-15$ YIL & $-0,155$ & 0,084 & 0,341 & $-0,392$ & 0,082 \\
\hline & & $\begin{array}{l}16 \text { YIL ve } \\
\text { USTU }\end{array}$ &,$- 23315^{*}$ & 0,080 & 0,039 & $-0,458$ & $-0,008$ \\
\hline & \multirow[t]{3}{*}{ 11-15 YIL } & $\begin{array}{l}5 \text { YIL ve } \\
\text { ALT I }\end{array}$ & 0,099 & 0,076 & 0,636 & $-0,114$ & 0,313 \\
\hline & & 6-10 YIL & 0,155 & 0,084 & 0,341 & $-0,082$ & 0,392 \\
\hline & & $\begin{array}{l}16 \text { YIL ve } \\
\text { USTU }\end{array}$ & $-0,078$ & 0,074 & 0,772 & $-0,286$ & 0,129 \\
\hline & \multirow[t]{3}{*}{$\begin{array}{l}16 \text { YIL ve } \\
\text { USTU }\end{array}$} & $\begin{array}{l}5 \text { YIL ve } \\
\text { ALTI }\end{array}$ & 0,178 & 0,071 & 0,104 & $-0,022$ & 0,378 \\
\hline & & 6-10 YIL &, $23315^{*}$ & 0,080 & 0,039 & 0,008 & 0,458 \\
\hline & & 11-15 YIL & 0,078 & 0,074 & 0,772 & $-0,129$ & 0,286 \\
\hline
\end{tabular}

\subsubsection{Staff}

This variable cannot be interpreted statistically due to variances are equal and sample are found to be homogenous. For the last decades, scientists, teachers, decision makers from around the world have dedicated themselves to increase people's consciousness of the environment. In spite of a great deal of both general and specific researches into people's environmental consciousness, there are very few studies searching level of environmental awareness of the teacher's and managers at schools. As one of the research on this area, this study shows that there are significant differences between demographical qualities of school managers/teachers and their environmental awareness.

A below final model constructed based on the results of this empirical study to illustrate which variables appear to be the most influential in teachers' and managers' environmental awareness. As a conclusion, the following demographic variables (gender, position, seniority) were found to be associated with environmental awareness. Based on the start up proposed model, knowledge attitude, behavior with tree sub dimensions called concern, communication and consciousness were obtained in this study. Following model of environmental awareness is structured as the final model. 
Figure 2: Final Model of the Study

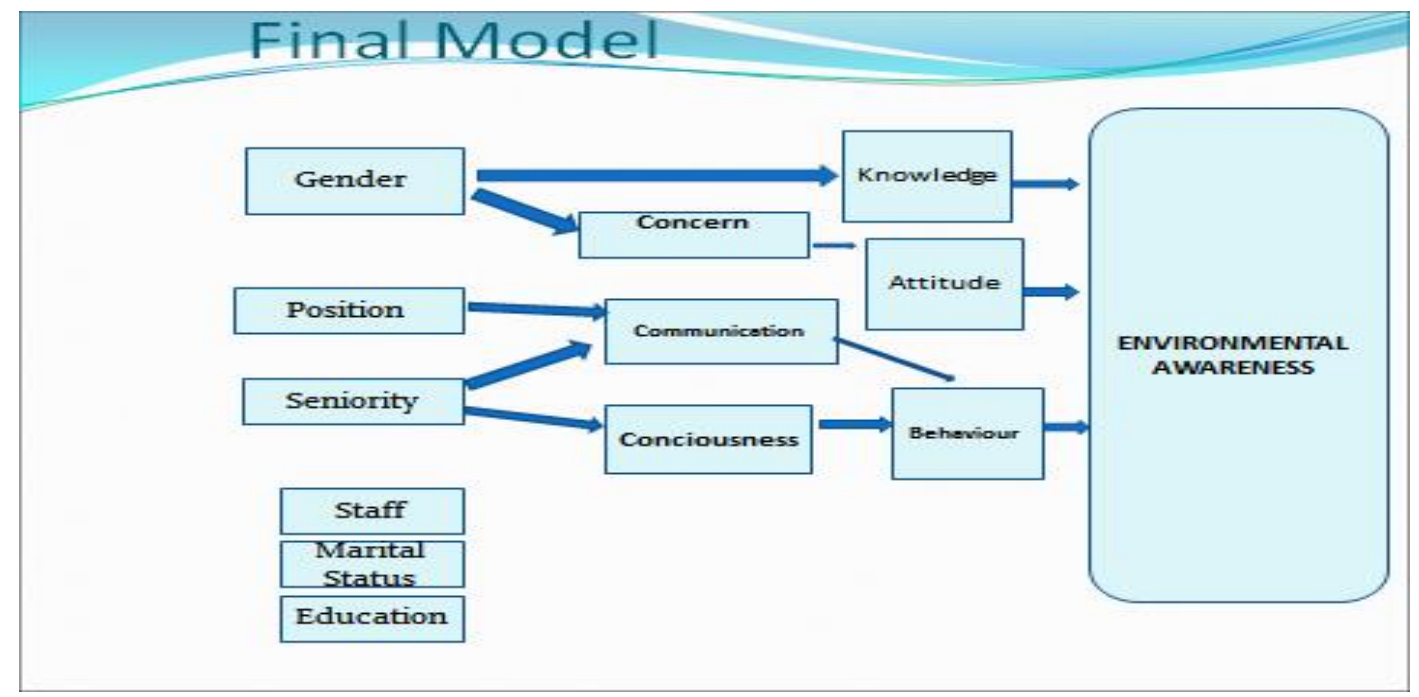

The results of the research shows that there is no difference between female and male groups in terms of environmental cautiousness, consciousness and communication. However, there are significant differences between female and male teachers and administrators in terms of environmental concern and knowledge. The knowledge and concern about environment of females private school teachers and managers is higher than males ones. It can be interpreted that to have more knowledge increases concern on environmental issues.

There is no difference between married and single teachers and managers in terms of environmental concern, cautiousness, communication, consciousness and knowledge. Moreover, any difference between graduate and post-graduate teachers in terms of environmental concern, cautiousness, communication, consciousness and knowledge have not been obtained. Both administrators and instructors have the same levels of concern, cautiousness, consciousness and knowledge about environmental issues whereas communication on environment differs between these two groups. Managers communicate more on environmental issues than instructors. When we look at the teachers' and managers seniority there is no difference according to their working years at school in terms of environmental concern, environmental cautiousness and environmental knowledge. Nevertheless, environmental communication and environmental consciousness vary according to the years of seniority. Teachers who have been working more than sixteen years, they communicate more on environmental issues in the society. That result suggests that since managers attend more to communicate and senior teachers more than sixteen years are more conscious on environmental issues.

\section{CONCLUSION}

It is clear that researches on all stakeholders of education could contribute to responsible living in order to better understand the current situation and design sustainability. Identification of problems will contribute to the solution of problems of all educational stakeholders. These kinds of research studies can be conducted in different cities in Turkey or different countries. Based on these researches, institutions should do more to promote environmental awareness programs in teacher education curricula by taking into consideration teachers and administrators demographical qualities. Instead of transmissive (transfer of information to learner) teaching methodologies, it is expected that institutions start to use new techniques like transformative (learner constructing and owning meaning) methodologies that go beyond the teaching method to also reflect the philosophy and purpose of sustainability education (Training Manuel, PERL, 2007). The authorities can lead programs to increase awareness of the society with the support of senior and administrative teachers in order to broaden the environmental awareness of their staff to use them as a pioneer. 


\section{REFERENCES}

Aragon-Correa, J.A., Garcia-Moreales, V.J. and Cordon-Pozo, E. (2007), Leadership and organizational learning's role on innovation and performance: Lessons from Spain, Industrial Marketing Management, 36, pp.349-359.

Ayhan, F.N. (1999). İlköğretim İlk Üç Sınıfındaki Öğrencilerin Yakın Çevre Bilincini Etkileyen Etmenler. Hacettepe Üniversitesi Sosyal Bilimler Enstitüsü Yüksek Lisans Tezi. Ankara.

Baş O. (2011) "Ortaöğretim Kurumlarında Çevre Bilincinin Yöneticiler Ve Öğretmenler Tarafından Algılanma Ve Benimsenme Düzeyi” Maltepe Üniversitesi S.B.E.Yüksek Lisans Tezi. İstanbul.

Bükük A. (2012) “Kuzey Kıbrıs Türk Cumhuriyeti Orta Ögretim Kurumlarında Görev Yapan Yönetici Ve Ögretmenler Tarafından Çevre Bilincinin Algılanması: Güzelyurt Örnegi." KKTC Yakın Dogu Üniversitesi Egıtim Bilimleri Enstitüsü Çevre Egitimi Ve Yönetimi Anabilim Dalı. Yüksek Lisans Tezi.Lefkoşa

Durmuş, S.B, Yurtkoru E.S, Çinko M. (2010), Sosyal Bilimlerde SPSS’le Veri Analizi, pp. 71-134

Erten, S. (2003). 5. Sınıf Öğrencilerinde Çöplerin Azaltılması Bilincinin Kazandırılmasına Yönelik Bir Öğretim Modeli. Hacettepe Üniversitesi Eğitim Fakültesi Dergisi. Sayı:25. Ankara.

Erten, S. (2002), illköğretimin 2. Kademesindeki (6.7.8. Sınıflar) Öğrencilerde Çevreye Yararlı Davranışların Araştırılması. V.Ulusal Fen Bilimleri ve Matematik Eğitimi Kongre Kitabı. Ankara.

Erten,S. (2004). Çevre Eğitimi Ve Çevre Bilinci Nedir, Çevre Eğitimi Nasıl Olmalıdır?, Çevre ve insan Dergisi, Çevre ve Orman Bakanlığı Yayın Organı. Sayı 65/66. 2006/25 Ankara

Erten, S. (2005). Okul Önce Öğretmen Adaylarında Çevre Dostu Davranışların Araştırılması. Hacettepe Üniversitesi Eğitim Fakültesi Dergisi. Sayı:28. 91-100. Ankara.

Erten, S. (2007). Ekosentrik, Antroposentrik ve Çevreye Yönelik Antipatik Tutum Ölçeğinin Türkçeye Uyarlama Çalışması

Egitim Arastirmalari - Eurasian Journal of Educational Research, 28, pp, 67-74

Erten, S. (2008). Insights to ecocentric, anthropocentric and antipathetic attitudes towards environment in diverse cultures. Egitim Arastirmalari - Eurasian Journal of Educational Research. 33, 141-156.

Eagles, Paul F.J. Ve Robert Demare. Factors Influencing Children's Environmental Attitudes. The Journal Of Environmental Education, 30 (4), 33,1999 .

Ford, P. (1986). Outdoor education: Definition and philosophy. (ERIC Document Reproduction Service No. ED267941).

Haktanır, G., Çabuk, B. (2000). Okul Öncesi Dönemde Çocukların Çevre Algısı. Hacettepe Üniversitesi IV. Fen Bilimleri Eğitim Kongresi. Ankara.

Kuhlemeier, Hans, Huub Van Denberg Ve Nijs Lagerwejg Environmental Knowledge, Attitzıdes And Behavior İn Dutch Secondary Education. The Journal Of Environmental Education, 30 (2), 4-14. . 1999

Kollmuss A. \& Agyeman J. "Mind the gap: why do people act environmentally and what are the barriers to pro-environmental behavior?" Environmental Education Research, Vol. 8, No. 3, 2002. pp. 239-260

Matten, D. \& Crane, A. (2005) Corporate Citizenship: Toward an Extended Theoretical Conceptualization. Academy of Management Review; Jan, Vol. 30, Issue 1, 14p

Mert, M. (2006). Lise Öğrencilerinin Çevre Eğitimi Katı Atıklar konusundaki Bilinç Düzeylerinin Saptanması. Hacettepe Üniversitesi Orta Öğretim Fen ve Matematik Anabilim dalı (Yüksek Lisans Tezi) Ankara

MA, Xın ve David J. BATESONA Multivariate Anaiysis of Relationship Between Attitudes Toward Science and Attitudes Toward the Environment. The Journal of Environmental Education, 31 (1), 27-32. 1999

McCrea, E. J. (2006). The roots of environmental education: How the past supports the future. Retrieved September 07,2006 from www.eetap.org.

Stapp, W.B.; et al. (1969). "The Concept of Environmental Education" (PDF). The Journal of Environmental Education. 1 (1): 30-31.

Şama, E. (1997) Üniversite Gençliğinin Çevre ve Çevre Sorunlarına Yönelik Tutumları-Gazi Eğitim Fakültesi Öğrencileri Üzerine Bir Araştırma. Gazi Üniversitesi Sosyal Bilimler Enstitüsü (Yayınlanmamış Doktora Tezi). Ankara.

Thoresen W. (2005). Consumer Citizenship Education Guidelines Vol.1. The Consumer Citizenship Network 2005 , p. 36.

Ürey, M. (2009) Öğretmen adaylarının çevreye yönelik akademik başarılarının bireyin çevre ve insan merkezli tutumları üzerine etkisi, yüksek lisans tezi Karadeniz Teknik Üniversitesi, Trabzon

Yücesoy, T. (2007) Türk Silahlı Kuvvetlerinde Çevre Bilinci Çalışması, Yayınlanmış Yüksek Lisans Tezi, İstanbul Ticaret Üniversitesi Fen Bilimleri Enstitüsü, İstanbul. 
Yılmaz, A., Morgil, İ., Aktuğ, P., Göbekli, İ. (2002). Ortaöğretim ve Yüksek Öğretim Öğrencilerinin Çevre, Çevre Kavramları ve Sorunları Konusundaki Bilgileri ve Önerileri. Hacettepe Üniversitesi Eğitim Fakültesi Dergisi. (22), 156-162. Ankara.

Training Manual. For facilitators of teacher training seminars on education for Responsible Living. 2011.PERL - Partnership for Education and Research about Responsible Living Hedmark University College, Hamar, Norway http://www.perlprojects.org/

(https://www.uia.org/s/or/en/1100055846) 